\section{INTERELASI DETERMINAN LOYALITAS PELANGGAN LAYANAN KARTU PRABAYAR GSM SIMPATI}

\section{DETERMINANTS INTERRELATION OF CUSTOMER LOYALTY OF GSM SIMPATI PREPAID SERVICE}

\author{
Devi Ayuni ${ }^{1}$, Andy Mulyana ${ }^{2}$ \\ Fakultas Ekonomi Universitas Terbuka \\ 1devi@ut.ac.id, ${ }^{2}$ mulyana@ut.ac.id
}

\begin{abstract}
Abstrak
Industri telekomunikasi telah berkembang dengan pesat dalam beberapa decade terakhir. Deregulasi pada sector telekomunikasi membuka peluang yang lebih besar bagi perusahaan-perusahaan telekomunikasi untuk bersaing dalam penyediaan layanan seluler. Salah satu strategi untuk bertahan hidup yang ditempuh adalah dengan membangun kesetiaan pelanggan. Tujuan riset ini adalah untuk menganalisis inter-relasi determinan-determinan dari kesetiaan yang terdiri atas kualitas jasa, nilai yang dipersepsikan, dan kepuasan pelanggan. Populasi yang digunakan dalam studi ini adalah pengguna kartu pra bayar GSM Simpati. Adapun pengolahan data dilakukan menggunakan SEM dengan bantuan perangkat lunak LISREL 8.7. Validitas dan reliabilitas diukur menggunakan confirmatory factor analysis (CFA). Dari enam hipotesis, lima di antaranya diterima sedangkan lainnya ditolak. Kualitas jasa memiliki pengaruh positif terhadap nilai yang dipersepsikan dan kepuasan pelanggan namun tidak memiliki pengaruh terhadap kesetiaan pelanggan. Pengaruh kualitas jasa terhadap kepuasan adalah lebih besar daripada pengaruh kualitas jasa terhadap nilai yang dipersepsikan. Kepuasan dan kesetiaan dipengaruhi oleh nilai yang dipersepsikan pelanggan. Pengaruh dari nilai yang dipersepsikan terhadap kesetiaan adalah lebih besar daripada terhadap kepuasan. Kesetiaan pelanggan mempengaruhi kepuasan pelanggan secara positif dan signifikan. Berdasarkan pada kontribusi dari indikator dari konstruk, untuk memperoleh kesetiaan pelanggan, Telkomsel perlu memelihara dan meningkatkan cakupan wilayah, kualitas suara, kualitas hubungan, dan kualitas sinyal dari Simpati. Dengan peningkatan dari kualitas, pelanggan akan merasakan nilai yang positif termasuk pengorbanan tenaga, upaya, dan waktu dari pelanggan. Sebagai tambahan, hal ini akan menciptakan kepuasan pelanggan yang menggunakan layanan kartu pra bayar GSM Simpati dan memberikan rekomendasi dan komunikasi mulut ke mulut yang positif.
\end{abstract}

Kata Kunci: kualitas jasa, nilai yang dipersepsikan, kesetiaan, kartu pra bayar Abstract

In recent decades the mobile telecommunications technology has grown very rapidly. The deregulation of the telecommunications sector opens greater opportunities for telecommunications companies to compete to provide cellular service. One of the survival strategies undertaken by establishing customer loyalty. The purpose of this research is to analyze the determinants of loyalty interrelation consisting of service quality, perceived value and customer satisfaction. The population used in this study were Simpati GSM prepaid card users. For the purposes of quantitative analysis, determination of scores for each item questionnaire used a Likert Scale. While processing the data using SEM with LISREL 8.7 software assistance. Validity and reliability using Confirmatory Factor Analysis (CFA). From six hypothesis, 5 were accepted while another one is rejected. Service quality had positive effect on perceived value and customer satisfaction, but had no effect on customer loyalty. The influence of service quality on satisfaction is greater than the influence of service quality on perceived value. Service satisfaction and loyalty are influenced by perceived customer value. The influence of perceived value on loyalty greater than the satisfaction. Customer loyalty is positively and significantly influenced by customer satisfaction. Based on the contribution of indicator constructs, to achieve customer loyalty as the Telkomsel GSM prepaid card providers need to maintain and improve Simpati area range, sound quality, connection and signal quality. With the improvement of the quality, the customer will feel the positive perceived value that includes the sacrifice of
JURNAL

MANAJEMEN INDONESIA

Vol.16 - No.2

APRIL 2016 


\section{JURNAL}

MANAJEMEN

INDONESIA

Vol.16 - No.2

APRIL 2016

Tabel 1.

Churnrate Pelanggan

Kartu Prabayar di Asia energy, effort, and time the customer. Additionally, it will create customer satisfaction that keeps the Simpati GSM prepaid card service as well as providing recommendations and positive word of mouth to others.

Keywords: service quality, perceived value, satisfaction, loyalty, prepaid cards

\section{Pendahuluan}

Dalam beberapa dasarwarsa terakhir, teknologi telekomunikasi seluler telah berkembang secara pesat. Perkembangan tersebut tidak hanya meliputi sistem operasi seperti Nordic Mobile Telephone (NMT), Advance Mobile Phone System (AMPS), Global System For Mobile Communication (GSM), dan kemudian CDMA (Code Division Multiple Access), tetapi juga meliputi jenis, fungsi, dan fitur telepon seluler. Sejak berlakunya Undang-Undang Telekomunikasi No. 36 Tahun 1999, sektor telekomunikasi memasuki era privatisasi dan keterbukaan pasar. Berdasarkan undang-undang ini, tidak ada hambatan bagi sebuah perusahaan untuk menjadi operator telekomunikasi di Indonesia. Hingga akhir tahun 2013, di Indonesia terdapat 10 operator telepon seluler dengan basis GSM dan CDMA. Indonesia merupakan pasar telepon seluler terbesar ke-3 di dunia (Frost dan Sullivan, 2010). Pada tahun 2011, menurut survey ROA Holding Analysis, terdapat lebih dari 245 juta pengguna telepon seluler dengan 97,5\% diantaranya merupakan pelanggan kartu prabayar (prepaid subscribers). Bahkan pelanggan kartu prabayar di Indonesia berada pada kisaran $99 \%$ (Prahadi, 2015),

Dengan adanya potensi pasar pengguna telepon seluler yang demikian besar, kompetisi diantara operator telekomunikasi semakin ketat untuk menarik dan mempertahankan pelanggan. Operator-operator telekomunikasi seluler berusaha mendesain ulang strategi dan bisnis untuk bertahan dan meningkatkan keunggulan bersaing mereka. Salah satu strategi bertahan yang dilakukan dengan cara mempertahankan pelanggan yang ada daripada mencari pelanggan baru (Lai et al., 2009). Menurut survey ROA Holding Analysis, perpindahan pelanggan dari satu operator ke operator lain (churnrate) di Indonesia merupakan yang tertinggi diantara negara-negara Asia lainnya (Tabel 1). Eakuru dan Mat (2008) menyatakan tujuan utama perusahaan adalah membangun loyalitas pelanggan. Adanya loyalitas pelanggan dapat mengurangi biaya operasi dan akuisisi perusahaan. Peningkatan retensi pelanggan sebesar 5\% akan meningkatkan keuntungan perusahaan antara 25-75\% (Reichheld dan Sasser, 1990). Diperlukan biaya lima kali lebih besar untuk mencari pelanggan baru daripada mempertahankan pelanggan yang ada (Wils, 2009). Disamping itu, perusahaan dapat meningkatkan tingkat pendapatannya melalui pelanggan yang loyal. Sebagai contoh, pertama, pelanggan yang loyal memiliki sensitivitas harga yang rendah. Pada industri asuransi, pelanggan yang loyal meningkatkan premi $8 \%$ per tahun (Reichheld dan Teal, 1996). Kedua, pelanggan yang loyal mau membeli lebih sering, mencoba produk atau jasa lain perusahaan, dan menarik pelanggan baru pada perusahaan (Reichheld dan Sasser, 1990). Loyalitas pelanggan memberikan dasar bagi perusahaan untuk menguji strategi pemasaran, kualitas hubungan pelanggan dan program penciptaan nilai yang mereka miliki (Reichheld dan Sasser, 1990).

\begin{tabular}{ccc}
\hline No & Negara & Churnrate \\
\hline 1. & Indonesia & $12 \%$ \\
2. & Vietnam & $10 \%$ \\
3. & India & $7 \%$ \\
4. & Filipina & $5 \%$ \\
5. & China & $4 \%$ \\
6. & Korea & $3 \%$ \\
7. & Malaysia & $3 \%$ \\
8. & Taiwan & $2 \%$ \\
9. & Singapura & $2 \%$ \\
10. & Jepang & $1 \%$ \\
\hline \multicolumn{2}{r}{ Sumber: } & ROA Holding Analysis $(2011)$
\end{tabular}

Perusahaan-perusahaan yang memberikan kualitas jasa superior dapat lebih memuaskan pelanggannya (Gilbert dan Veloutsou, 2006). Kepuasan pelanggan adalah pendorong utama loyalitas pelanggan dan kesuksesan bisnis (Oliver, 1997). Beberapa 
penelitian memberikan bukti positif hubungan langsung antara kepuasan pelanggan dan loyalitas melalui pembelian ulang, kurangnya sensitivitas harga, perilaku pembelian silang, dan profitabilitas (Ibrahim dan Najjar, 2008; Bloemer dan Odekerben - Schroder, 2002).

Banyak perusahaan berusaha untuk memberikan nilai lebih bagi pelanggan dalam rangka memuaskan pelanggan dengan cara membangun hubungan jangka panjang dan keuntungan bersama (Kotler, 2005). Bila produk atau jasa tidak memenuhi kebutuhan dan keinginan pelanggan, maka seluruh strategi pemasaran menjadi sia-sia. Oleh karena itu, tujuan penelitian ini adalah untuk mencari perbedaan pengaruh kualitas jasa, nilai persepsian pelanggan dan kepuasan pelanggan terhadap loyalitas pelanggan kartu prabayar GSM. Perubahan paradigma bisnis saat ini telah menempatkan kualitas jasa sebagai prioritas utama (Taylor dan Baker, 1994). Evaluasi pelanggan terhadap kualitas jasa merupakan faktor kritikal bagi perusahaan untuk meningkatkan strategi pemasarannya (Jain dan Gupta, 2004). Perhatian terhadap kualitas jasa dapat membuat perusahaan berbeda dari perusahaan lain dan memperoleh keuntungan kompetitif (Boshoff dan Gray, 2004). Pengukuran kualitas jasa memungkinkan perusahaan mengetahui posisi mereka dalam pasar dan mempersiapkan strategi persaingan (Khan, 2010).

Beberapa penelitian terdahulu menyatakan bahwa kualitas jasa adalah indikator penting dari kepuasan pelanggan (Spreng dan Machoy, 1996). Kepuasan pelanggan dipandang sebagai pengaruh niat pembelian ulang dan perilaku yang mempengaruhi pendapatan dan keuntungan perusahaan di masa datang. Pelanggan yang puas mungkin tidak akan kembali dan mengatakan word of mouth positif kepada orang lain (Bowen dan Shoemaker, 2003). Salah satu penyebabnya karena perusahaan tidak bisa memberikan kebutuhan atau keinginan pelanggan (Roig et al., 2006). Selain itu, pengukuran kepuasan pelanggan tanpa mempertimbangkan pemenuhan nilai persepsian tidak sepenuhnya memuaskan ekspektasi pelanggan (Woodruff, 1997). Oleh karena itu diperlukan beberapa variabel lain untuk menjelaskan hubungan antara kepuasan dan loyalitas pelanggan.

Nilai persepsi pelanggan diidentifikasikan melalui terminologi nilai (Monroe, 1990; Zeithaml 1988) atau nilai pelanggan (Butz dan Goodstein, 1996). Pengiriman nilai kepada pelanggan bertujuan membangun pelanggan yang loyal yang dapat meningkatkan frekuensi dan kuantitas pembelian serta tidak mengindahkan perilaku perpindahan (Rust et al., 2004). Keunggulan kompetitif perusahaan dapat dibangun dengan cara membentuk nilai pelanggan (Lee dan Overby, 2004). Nilai persepsian pelanggan sebagai evaluasi keseluruhan pelanggan terhadap produk berdasarkan persepsi apa yang didapat dan apa yang diberikan (Zeithaml, 1988). Nilai persepsian pelanggan sebagai variabel dinamis yang didapat setelah konsumsi (Moliner et al., 2007). Nilai adalah persepsi nilai fungsional dari kualitas dan harga barang atau jasa, nilai emosional, dan nilai social dampak dari pengalaman pribadi dan pilihan-pilihan lainnya (Moliner et al., 2007). Nilai persepsian pelanggan sebagai proses dari aspek pra pembelian, transaksi, dan pasca pembelian dalam berbagai situasi (Woodruff, 1997).

Loyalitas pelanggan dapat diklasifikan menjadi loyalitas merek, loyalitas jasa, dan loyalitas toko (Dick dan Basu, 1994). Loyalitas pelanggan adalah strategi menciptakan keuntungan bersama antara perusahaan dan pelanggan (Reichheld dan Detrick, 2003). Salah satu keuntungan loyalitas adalah peningkatan pendapatan perusahaan. Dengan memiliki pelanggan yang loyal, perusahaan dapat memaksimumkan keuntungannya karena pelanggan yang loyal membeli lebih sering, menghabiskan lebih banyak uang untuk produk atau jasa baru, dan merekomendasikan produk atau jasa pada orang lain (Reichheld dan Sasser, 1990). Selain itu, loyalitas berkaitan erat dengan kesuksesan dan profitabilitas perusahaan (Eakuru dan Mat, 2008).

Berdasarkan kajian penelitian sebelumnya, maka terdapat beberapa hipotesis penelitian yang terdiri dari:

H1 :kualitas jasa berpengaruh terhadap persepsi nilai pelanggan

H2 :kualitas jasa berpengaruh terhadap kepuasan pelanggan

H3 : kualitas jasa berpengaruh terhadap loyalitas pelanggan

H4 : persepsi nilai pelanggan berpengaruh terhadap kepuasan pelanggan

H5 :persepsi nilai pelanggan berpengaruh terhadap loyalitas pelanggan

H6 :kepuasan pelanggan berpengaruh terhadap loyalitas pelanggan 


\section{JURNAL}

MANAJEMEN

INDONESIA

Vol.16 - No.2

APRIL 2016

Gambar 1.

Model Penelitian

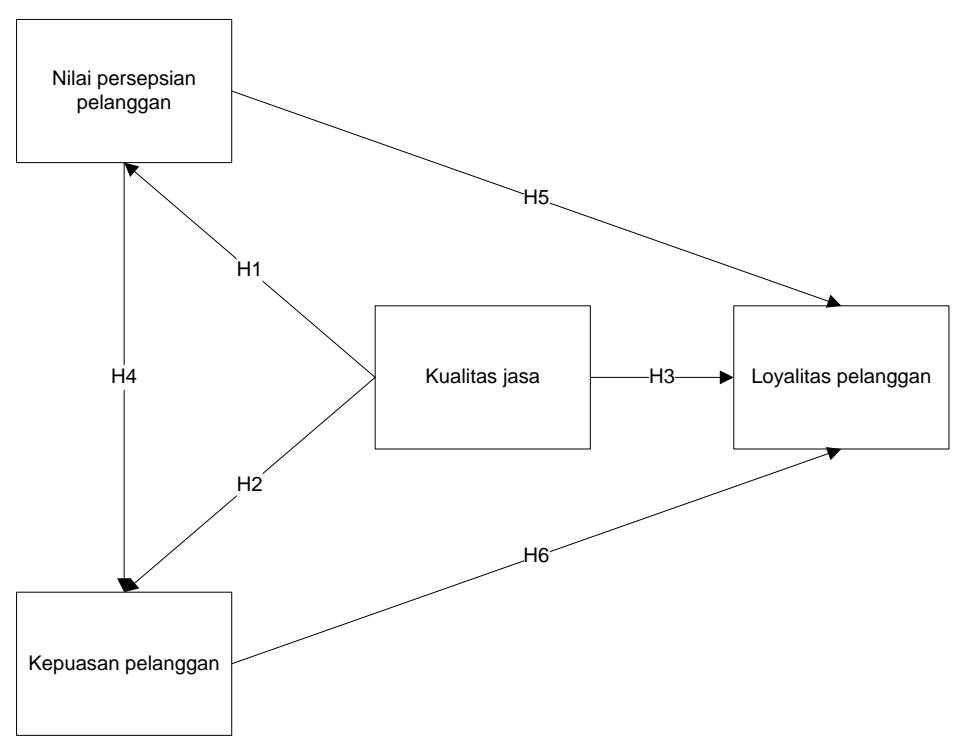

\section{Landasan Teori dan Metodologi}

Penelitian ini menggunakan metode nonprobability sampling dengan teknik judgemental samplingi. Populasi penelitian yaitu mahasiswa yang menggunakan kartu prabayar GSM Simpati di Jakarta. Perbandingan 5 sampai 10 responden pada setiap observed variable dapat terpenuhi untuk distribusi normal ketika sebuah latent variable memiliki beberapa indikator (Bentler dan Chou, 1987). Pada penelitian ini terdapat 26 indikator, sehingga diperlukan sampel berukuran minimum $26 \times 10=260$ responden. Dari hasil penyebaran kuesioner, terdapat 300 kuesioner lengkap yang dapat diproses.

Penelitian ini menggunakan dua jenis data, yaitu, data primer melalui survey dengan memberikan kuesioner di lokasi penelitian. Sementara data sekunder didapat dari berbagai buku, jurnal, tesis, disertasi, literatur dan internet yang dianggap relevan. Pengukuran data yang akan dilakukan menggunakan skala Likert dengan ukuran sebagai berikut: $1=$ Sangat Tidak Setuju, 2 = Tidak Setuju, 3 = Kurang Setuju, $4=$ Setuju, $5=$ Sangat Setuju.

Penelitian ini terdiri dari 4 konstruk, yaitu kualitas jasa, nilai persepsian, kepuasan, dan loyalitas. Konstruk kualitas jasa diadaptasi dan dikembangkan memiliki 11 indikator yang terdiri dari kualitas jangkauan area, kualitas sinyal, kualitas suara, kualitas tingkat koneksi jaringan telephon, kualitas teknologi seluler, kualitas produk sesuai dengan slogan, kualitas fitur dan layanan, kualitas pelayanan call center yang responsif, kualitas pelayanan call center yang handal, kualitas pelayanan keluhan dan informasi, dan kualitas prosedur pelayanan (Lai et al., 2009).

Sedangkan konstruk nilai persepsian diadaptasi dan dikembangkan berdasarkan penelitian (Moliner et al., 2007) terdiri dari 4 indikator, yaitu layanan yang diberikan kartu prabayar GSM Simpati bernilai positif, layanan yang diberikan kartu prabayar GSM Simpati sesuai dengan waktu yang dikorbankan, layanan yang diberikan kartu prabayar GSM Simpati sesuai dengan tenaga yang dikorbankan, dan layanan yang diberikan kartu prabayar GSM Simpati sesuai dengan usaha yang dikorbankan.

Selanjutnya konstruk kepuasan pelanggan diadaptasi dan dikembangkan berdasarkan penelitian (Oliver, 1997) terdiri dari 6 indikator yaitu dibandingkan dengan operator lain, pelanggan sangat puas dengan kartu prabayar GSM Simpati; berdasarkan pengalaman, pelanggan sangat puas dengan kartu prabayar GSM Simpati; pelanggan puas dengan harga yang ditawarkan oleh kartu prabayar GSM Simpati; pelanggan puas dengan kualitas yang ditawarkan oleh kartu prabayar GSM Simpati; pelanggan puas dengan pelayanan yang diberikan kartu prabayar GSM Simpati; dan kartu prabayar GSM Simpati memberikan kepuasan produk.

Konstruk terakhir, loyalitas, terdiri atas 5 indikator berikut yang diadaptasi dan dikembangkan berdasarkan penelitian (Aydin dan Ozer, 2005), yaitu Saya akan terus menggunakan jaringan GSM Simpati, jika Saya ingin membeli kartu perdana prabayar baru, Saya lebih memilih jaringan kartu prabayar GSM Simpati, Saya merekomendasikan kartu prabayar GSM Simpati kepada orang lain, Saya meyakinkan teman agar membeli kartu 
prabayar GSM Simpati, walaupun operator lain lebih murah, tetapi Saya tetap menggunakan kartu prabayar GSM Simpati.

Program Lisrel 8.7 digunakan untuk menganalisis hubungan kausal penelitian berbentuk Structural Equation Modeling (SEM). Model penelitian dianalisis menggunakan pendekatan dua tahap. Tahap pertama berfokus pada model pengukuran dimana hasil estimasi dianalisis kemudian dilakukan uji kecocokan seluruh model agar terlihat validitas dan reliabilitas konstruk. Tahap selanjutnya menganalisis model struktural dengan tujuan melihat hubungan diantara konstruk (Wijanto, 2008).

Confirmatory Factor Analysis (CFA) dengan bantuan software Linear Structural Relationship Lisrel 8.7 digunakan untuk uji validitas dan reliabilitas. Pengukuran validitas dilakukan dengan melihat nilai $\mathrm{t}$ - value dan standard loading factor (SLF) variabel teramati masing-masing model CFA. Variabel teramati dianggap valid bila memiliki nilai $\mathrm{t}-$ value $\geq$ 1.96 dan $\mathrm{SLF} \geq 0.50$ (Igbaria et al., 1997 dalam Wijanto, 2008). Selanjutnya komposit reliabilitas dan ukuran ekstrak varian digunakan untuk mengukur reliabilitas. Nilai komposit reliabilitas dan ekstrak varian dianggap baik jika lebih besar dari 0.7 dan 0.5.

\section{Hasil dan Pembahasan}

\subsection{Karakteristik Responden}

Berdasarkan hasil penyebaran kuesioner kepada mahasiswa perguruan tinggi yang terletak di Jakarta, terkumpul 300 kuesioner yang dapat diolah menjadi data penelitian dengan karakteristik berikut.

\begin{tabular}{|c|c|c|c|}
\hline Pertanyaan & Keterangan & Persentase & \\
\hline \multirow[t]{2}{*}{ Pengguna Kartu Prabayar Lain } & $\mathrm{Ya}$ & $70.5 \%$ & Tahel 2 \\
\hline & Tidak & $29.5 \%$ & Karakteristik \\
\hline \multirow[t]{6}{*}{ Kartu Prabayar Lain Yg Digunakan } & As & $8 \%$ & Responden \\
\hline & Mentari & $8 \%$ & Nesponituen \\
\hline & IM3 & $25 \%$ & \\
\hline & $\mathrm{XL}$ & $14 \%$ & \\
\hline & Three & $32 \%$ & \\
\hline & Esia & $13 \%$ & \\
\hline \multirow[t]{2}{*}{ Jenis Kelamin } & Pria & $49 \%$ & \\
\hline & Wanita & $51 \%$ & \\
\hline \multirow[t]{2}{*}{ Status } & Menikah & $3.9 \%$ & \\
\hline & Belum Menikah & $96.1 \%$ & \\
\hline \multirow[t]{5}{*}{ Penghasilan (uang saku) per bulan } & $<\operatorname{Rp} 500.000,-$ & $36.1 \%$ & \\
\hline & Rp 500.000,- sd Rp 1.000.000,- & $38.9 \%$ & \\
\hline & $\begin{array}{llll}\mathrm{Rp} & 1.000 .000,- & \mathrm{sd} & \mathrm{Rp}\end{array}$ & $18.3 \%$ & \\
\hline & $2.000 .000,-$ & & \\
\hline & $>\operatorname{Rp} 2.000 .000,-$ & $6.7 \%$ & \\
\hline Lama penggunaan layanan kartu & $<1$ tahun & $32.8 \%$ & \\
\hline \multirow[t]{2}{*}{ prabayar GSM Simpati } & $1-2$ tahun & $37.2 \%$ & \\
\hline & $>2$ tahun & $28 \%$ & \\
\hline \multirow[t]{3}{*}{ Fasilitas yg sering digunakan } & Menelepon & $57.8 \%$ & \\
\hline & SMS/MMS & $14.14 \%$ & \\
\hline & Internet/mengirim data & $27.8 \%$ & \\
\hline \multirow[t]{3}{*}{ Nomor yg paling sering dihubungi } & PSTN & $3.8 \%$ & \\
\hline & Sesama operator & $69.7 \%$ & \\
\hline & Antar operator & $26.7 \%$ & \\
\hline \multirow[t]{3}{*}{ Siapa yg paling sering dihubungi } & Keluarga & $53.9 \%$ & \\
\hline & Teman & $33.3 \%$ & \\
\hline & Relasi & $2.8 \%$ & \\
\hline \multirow[t]{3}{*}{ Frekuensi pembelian pulsa per bulan } & 1 kali & $20.6 \%$ & \\
\hline & $2-3$ kali & $62.8 \%$ & \\
\hline & $>3$ kali & $16.7 \%$ & \\
\hline \multirow{3}{*}{$\begin{array}{l}\text { Biaya pembelian pulsa isi ulang per } \\
\text { bulan }\end{array}$} & $<100.000$ & $75.1 \%$ & \\
\hline & $100.000 \mathrm{sd} 200.000$ & $20 \%$ & \\
\hline & $>300.000$ & $5 \%$ & \\
\hline
\end{tabular}


JURNAL

MANAJEMEN

INDONESIA

Vol.16 - No.2

APRIL 2016

\section{Sumber: Data diolah}

Sebagian besar responden menggunakan kartu prabayar lain selain kartu prabayar GSM Simpati. Kartu prabayar Three dan IM3 merupakan kartu prabayar selain Simpati yang banyak digunakan oleh responden. Komposisi responden pria dan wanita cukup seimbang. Adapun sebagaimana layaknya mahasiswa sebagai responden, sebagian besar belum menikah dengan uang saku sebesar Rp 500 000,- sampai dengan Rp 1000 000,-. Kartu prabayar GSM Simpati telah digunakan sebagian besar responden selama 1-2 tahun dengan menelepon merupakan fasilitas yang paling sering digunakan. Hubungan telepon sesama operator paling sering dilakukan oleh responden karena dianggap paling murah. Keluarga dan teman adalah relasi yang paling dihubungi oleh responden. Frekuensi pembelian pulsa biasanya dilakukan sebanyak 2-3 sebulan dengan biaya pulsa kurang dari Rp 100 000,- dan nominal pulsa isi ulang Rp 50 000,-.

\subsection{Validitas dan Reliabilitas}

Validitas dan reliabilitas model pengukuran dievaluasi secara terpisah terhadap tiap model pengukuran atau konstruk. Hasil evaluasi muatan nilai faktor dan faktor standar diharapkan lebih besar dari 1.96 dan 0.50 (Igbaria et al., 1997 dalam Wijanto, 2008).

Seluruh variabel teramati (VAR1 - VAR26) memiliki validitas yang baik karena memiliki nilai $\mathrm{t}$ - value $>1.96$ dan nilai standar lebih besar dari 0.50 kecuali kualitas fitur dan layanan (VAR7), kualitas pelayanan call center yang handal (VAR9), dan kualitas jasa kartu prabayar GSM Simpati dibanding biaya yang dikeluarkan telah melebihi harapan (VAR23). Walaupun bernilai kurang dari 0.50 tetap dianggap valid karena masih di atas 0.30. Selain itu, dari estimasi standardize solution dapat diperoleh uji reliabilitas atau konsistensi suatu pengukuran. Reliabilitas kualitas jasa, nilai persepsian, kepuasan, dan loyalitas dilihat pada nilai $\mathrm{CR}>0.7$ dan VE $>0.5$ yang menunjukkan reliabilitas baik.
Tabel 3. Validitas dan Reliabilitas

\begin{tabular}{|c|c|c|c|c|c|c|c|c|c|c|c|}
\hline \multirow{2}{*}{$\begin{array}{c}\text { Variabel } \\
\text { Laten/Tera } \\
\text { mati }\end{array}$} & \multicolumn{2}{|c|}{ Kualitas Jasa } & \multicolumn{2}{|c|}{$\begin{array}{l}\text { Kepuasan } \\
\text { Pelanggan } \\
\end{array}$} & \multicolumn{2}{|c|}{ Loyalitas } & \multicolumn{2}{|c|}{ Nilai } & \multirow{2}{*}{$\begin{array}{l}\mathbf{C} \\
\mathbf{R}\end{array}$} & \multirow{2}{*}{ VE } & \multirow{2}{*}{$\underset{\mathbf{n}}{\text { Kesimpula }}$} \\
\hline & $\begin{array}{c}\mathbf{t}- \\
\text { value }\end{array}$ & $\begin{array}{l}\text { SL } \\
\text { F }\end{array}$ & $\begin{array}{c}\mathrm{t}- \\
\text { value }\end{array}$ & SLF & $\begin{array}{c}\mathrm{t}- \\
\text { value }\end{array}$ & $\begin{array}{c}\text { SL } \\
\mathbf{F}\end{array}$ & $\begin{array}{c}t- \\
\text { value }\end{array}$ & $\begin{array}{c}\text { SL } \\
\mathbf{F}\end{array}$ & & & \\
\hline $\begin{array}{c}\text { Kualitas } \\
\text { Jasa }\end{array}$ & & & & & & & & & $\begin{array}{c}0.8 \\
5\end{array}$ & 0.35 & $\begin{array}{c}\text { Reliabilitas } \\
\text { Baik }\end{array}$ \\
\hline VAR1 & 13.08 & 0.7 & & & & & & & & & $\begin{array}{c}\text { Validitas } \\
\text { Baik }\end{array}$ \\
\hline VAR2 & 11.66 & 0.64 & & & & & & & & & $\begin{array}{c}\text { Validitas } \\
\text { Baik }\end{array}$ \\
\hline VAR3 & 12.99 & 0.7 & & & & & & & & & $\begin{array}{c}\text { Validitas } \\
\text { Baik }\end{array}$ \\
\hline VAR4 & 13.99 & 0.74 & & & & & & & & & $\begin{array}{c}\text { Validitas } \\
\text { Baik }\end{array}$ \\
\hline VAR5 & 8.66 & 0.5 & & & & & & & & & $\begin{array}{c}\text { Validitas } \\
\text { Baik }\end{array}$ \\
\hline VAR6 & 9.82 & 0.56 & & & & & & & & & $\begin{array}{c}\text { Validitas } \\
\text { Baik }\end{array}$ \\
\hline VAR7 & 7.63 & 0.45 & & & & & & & & & $\begin{array}{c}\text { Validitas } \\
\text { Baik }\end{array}$ \\
\hline VAR8 & 9.24 & 0.53 & & & & & & & & & $\begin{array}{c}\text { Validitas } \\
\text { Baik }\end{array}$ \\
\hline VAR9 & 8.43 & 0.49 & & & & & & & & & $\begin{array}{c}\text { Validitas } \\
\text { Baik }\end{array}$ \\
\hline VAR10 & 8.69 & 0.5 & & & & & & & & & $\begin{array}{c}\text { Validitas } \\
\text { Baik }\end{array}$ \\
\hline VAR11 & 10.41 & 0.59 & & & & & & & & & $\begin{array}{c}\text { Validitas } \\
\text { Baik }\end{array}$ \\
\hline Kepuasan & & & & & & & & & $\begin{array}{c}0.8 \\
5\end{array}$ & 0.49 & $\begin{array}{c}\text { Reliabilitas } \\
\text { Baik } \\
\end{array}$ \\
\hline
\end{tabular}






Sumber: Hasil pengolahan data dengan analisis SEM

\subsection{Uji Kecocokan Seluruh Model}

Setelah diperoleh variabel teramati yang valid dan reliabel, maka tahap kedua analisis SEM two step approach dapat dilaksanakan. Model hybrid tahap kedua diperoleh dari penambahan model CFA tahap pertama pada model struktural asli. Kemudian model ini diuji kecocokan keseluruhan model SEM dan struktural. Uji kecocokan keseluruhan model SEM (Tabel 4) menunjukkan hasil yang cukup baik. Hal tersebut terlihat 9 dari 15 estimasi menunjukkan hasil baik, sedangkan hanya 6 lainnya kurang baik.

\begin{tabular}{llcc}
\hline $\begin{array}{c}\text { Ukuran } \\
\text { GOF }\end{array}$ & \multicolumn{1}{c}{ Target-Tingkat Kecocokan } & Hasil Estimasi & $\begin{array}{c}\text { Tingkat } \\
\text { Kecocokan }\end{array}$ \\
\hline Chi- & Nilai yang kecil $\mathrm{p}>0.05$ & $1592.92(\mathrm{P}=$ & Poor fit \\
Square & & $0.0)$ & \\
NCP & Nilai yang kecil interval yang sempit & $(1352.68 ;$ & Poor fit \\
Interval & & $1618.25)$ & Marginal fit \\
RMSEA & RMSEA $\leq 0.08$ & 0.13 & \\
p (close & P $<0.05$ & 0.00 & Good fit \\
fit) & & & \\
ECVI & Nilai yang kecil dan dekat dengan ECVI & M: 6.32 & S: 2.35 \\
& saturated & I: 36.97 & Good fit \\
AIC & Nilai yang kecil dan dekat dengan AIC & M: 1890.74 & S: 702.00 \\
& saturated & I: 11053.04 & \\
& & & \\
\hline
\end{tabular}

Tabel 4.

Hasil Uji

Kecocokan Keseluruhan Model

SEM

Tabel 3. Validitas dan Reliabilitas 
CAIC Nilai yang kecil dan dekat dengan CAIC saturated

JURNAL

MANAJEMEN

INDONESIA

Vol.16 - No.2

APRIL 2016

Tabel 4.

Hasil Uji

Kecocokan

Keseluruhan

Model SEM

Tabel 5. Resume Uji Hipotesis
NFI

$\mathrm{NFI} \geq 0.90$ good fit

$0.80 \leq \mathrm{NFI}<0.90$ marginal fit

NNFI

$\mathrm{NNFI} \geq 0.90$ good fit

$0.80 \leq \mathrm{NNFI}<0.90$ marginal fit

CFI

$\mathrm{CFI} \geq 0.90$ good fit

$0.80 \leq \mathrm{CFI}<0.90$ marginal fit

IFI

IFI $\geq 0.90$ good fit

$0.80 \leq$ IFI $<0.90$ marginal fit

RFI

$\mathrm{RFI} \geq 0.90$ good fit

$0.80 \leq \mathrm{RFI}<0.90$ marginal fit

$\mathrm{CN} \quad \mathrm{CN} \geq 200$

RMR Standardized RMR $\leq 0.05$

GFI $\quad$ GFI $\geq 0.90$ good fit

$0.80 \leq$ GFI $<0.90$ marginal fit

AGFI AGFI $\geq 0.90$ good fit

$0.80 \leq$ AGFI $<0.90$ marginal fit
Sumber: Hasil pengolahan data dengan analisis SEM

\subsection{Analisis Model Struktural} signifikan terhadap loyalitas pelanggan dengan $\mathrm{t}$ - value 6.78 .
Good fit

M: 2163.56

S: 2353.03

I: 11175.34

0.86

Marginal fit

0.86

Marginal fit

0.88

Marginal fit

0.88

Marginal fit

0.84

Marginal fit

67.12

Poor fit

$0.090 \quad$ Poor fit

$0.69 \quad$ Poor fit

$0.62 \quad$ Poor fit

Analisis model struktural dilakukan sebagai langkah lanjutan setelah pengujian kecocokan model SEM secara keseluruhan. Gambar 3 (Model t - value) menunjukkan signifikansi pengaruh antara konstruk. Dari 6 relasi antara keempat konstruk variabel laten, 5 diantaranya menunjukkan pengaruh yang signifikan. Signifikansi pengaruh terlihat dari besarnya nilai $\mathrm{t}$ - hitung di atas 1.96 . Konstruk kualitas jasa memiliki pengaruh positif dan signifikan terhadap nilai persepsian pelanggan dan kepuasan dengan $\mathrm{t}$ - value 5.99 dan 8.79. Sedangkan konstruk kualitas jasa tidak berpengaruh positif dan signifikan terhadap loyalitas pelanggan karena $\mathrm{t}$ - value kurang dari $1.96(\mathrm{t}-$ value $=-0.14)$. Kemudian nilai persepsian pelanggan berpengaruh positif dan signifikan terhadap kepuasan dan loyalitas pelanggan sebesar 2.15 dan 4.09. Dan terakhir, kepuasan pelanggan berpengaruh positif dan

Diantara kelima pengaruh signifikan tersebut, pengaruh terbesar dimiliki kepuasan terhadap loyalitas pelanggan sebesar 0.68 (gambar 4). Diikuti pengaruh kualitas jasa terhadap kepuasan 0.67 dan kualitas jasa terhadap nilai persepsian 0.47 . Kemudian pengaruh nilai persepsian terhadap loyalitas pelanggan dan kepuasan sebesar 0.26 dan 0.14 .

\begin{tabular}{|c|c|c|c|c|c|c|c|}
\hline \multirow{2}{*}{$\begin{array}{c}\text { Hipotesis } \\
1\end{array}$} & \multicolumn{2}{|c|}{ Jalur } & \multirow{2}{*}{$\begin{array}{c}\begin{array}{c}\text { Nilai } \\
-\mathbf{t}\end{array} \\
5.99\end{array}$} & \multirow{2}{*}{$\begin{array}{c}\text { Estimasi } \\
0.47\end{array}$} & \multicolumn{3}{|c|}{ Kesimpulan } \\
\hline & Kualitas Jasa terh & Idap Nilai & & & $\begin{array}{l}\text { Signifikan } \\
\text { diterima) }\end{array}$ & (Hipotesis & 1 \\
\hline 2 & $\begin{array}{ll}\text { Kualitas } & \text { Jasa } \\
\text { Kepuasan } & \end{array}$ & terhadap & 8.79 & 0.67 & $\begin{array}{l}\text { Signifikan } \\
\text { diterima) }\end{array}$ & (Hipotesis & 2 \\
\hline 3 & $\begin{array}{l}\text { Kualitas Jasa } \\
\text { Loyalitas Pelangg }\end{array}$ & $\begin{array}{l}\text { terhadap } \\
\text { an }\end{array}$ & -0.14 & -0.01 & $\begin{array}{l}\text { Tidak signi } \\
3 \text { tidak dite }\end{array}$ & $\begin{array}{l}\text { ikan (Hipot } \\
\text { ma) }\end{array}$ & \\
\hline 4 & Nilai terhadap Ke & puasan & 2.15 & 0.14 & $\begin{array}{l}\text { Signifikan } \\
\text { diterima) }\end{array}$ & (Hipotesis & 4 \\
\hline 5 & $\begin{array}{l}\text { Nilai terhadap } \\
\text { Pelanggan }\end{array}$ & Loyalitas & 4.09 & 0.26 & $\begin{array}{l}\text { Signifikan } \\
\text { diterima) }\end{array}$ & (Hipotesis & 5 \\
\hline 6 & $\begin{array}{l}\text { Kepuasan } \\
\text { terhadap } \\
\text { Pelanggan }\end{array}$ & $\begin{array}{r}\text { Pelanggan } \\
\text { Loyalitas }\end{array}$ & 6.78 & 0.68 & $\begin{array}{l}\text { Signifikan } \\
\text { diterima) }\end{array}$ & (Hipotesis & 6 \\
\hline
\end{tabular}

Sumber: Data diolah

Besarnya konstribusi variabel teramati terhadap pembentukan masing-masing konstruk dapat dilihat dari nilai model struktural estimates. Besarnya pengaruh masing-masing variabel diperoleh dengan mengalikan faktor muatan dengan koefisien konstruk variabel yang dibentuk (tabel 


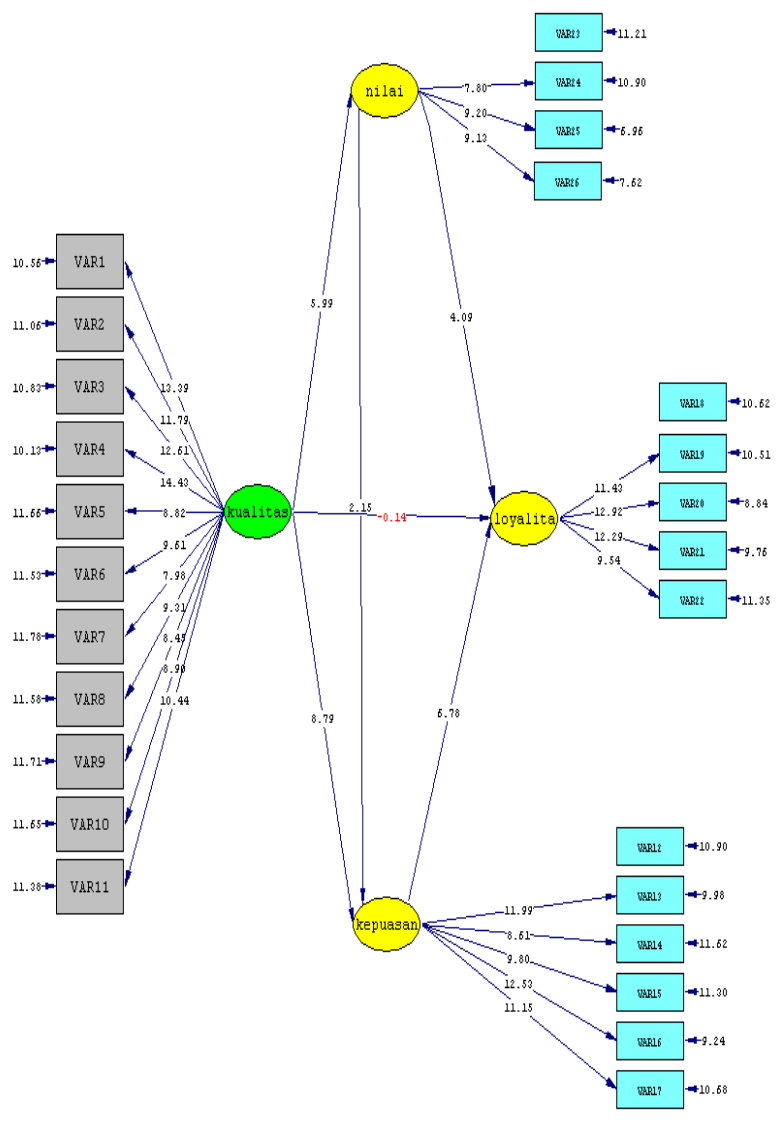

JURNAL

MANAJEMEN

INDONESIA

Vol.16 - No.2

APRIL 2016

Gambar 3.

Model t - value

Pada relasi kualitas jasa dengan nilai dan kualitas jasa dengan kepuasan, kontribusi tertinggi didapat dari kualitas jangkauan area. Kemudian diikuti oleh kualitas suara, kualitas tingkat koneksi, dan kualitas sinyal. Sedangkan kontribusi terendah disumbangkan oleh pelayanan call center, fitur dan layanan, prosedur pelayanan, dan pelayanan keluhan dan informasi.

Selanjutnya, pada relasi nilai persepsian dengan kepuasan dan nilai persepsian dengan loyalitas, dari 4 variabel teramati hanya 3 yang signifikan, yaitu nilai yang didapat sesuai dengan waktu, tenaga, dan usaha yang dikorbankan pelanggan. Kontribusi terbesar terdapat pada pengorbanan tenaga, diikuti pengorbanan usaha dan waktu.

Seperti pada relasi nilai persepsian dengan kepuasan dan loyalitas, pada relasi kepuasan dengan loyalitas terdapat 1 variabel teramati yang tidak signifikan, yaitu VAR12. Oleh karena itu, kontribusi variabel teramati pada relasi ini diperoleh dari 5 variabel teramati lainnya. Kelima variabel teramati tersebut yaitu berdasarkan pengalaman, pelanggan sangat puas dengan kartu prabayar GSM Simpati; pelanggan puas dengan pelayanan yang diberikan kartu prabayar GSM Simpati; kartu prabayar GSM Simpati memberikan kepuasan produk; pelanggan puas dengan harga yang ditawarkan oleh kartu prabayar GSM Simpati; pelanggan puas dengan kualitas yang ditawarkan oleh kartu prabayar GSM Simpati. 


\section{JURNAL}

\section{MANAJEMEN}

INDONESIA

\section{Vol.16 - No.2}

\section{APRIL 2016}

Gambar 4.

Model Estimates

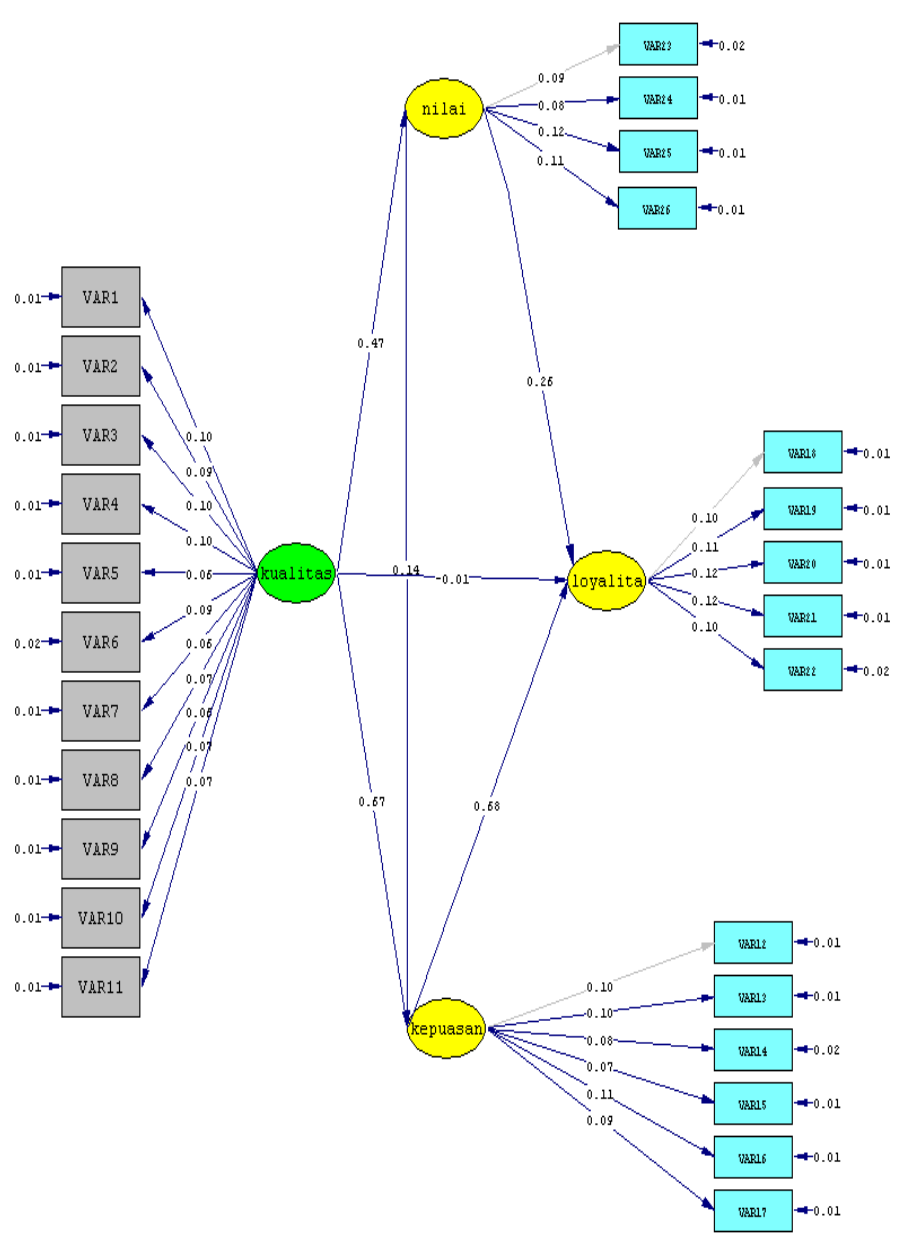

Tabel 6.

Kontribusi Variabel Teramati

Terhadap Pembentukan

Konstruk

\begin{tabular}{ccccc}
\hline $\begin{array}{c}\text { Variabel } \\
\text { Laten/Teramati }\end{array}$ & Pernyataan & $\begin{array}{c}\text { Faktor } \\
\text { Muatan }\end{array}$ & $\begin{array}{c}\text { Koefisien } \\
\text { Konstruk }\end{array}$ & Kontribusi \\
\hline $\begin{array}{c}\text { Kualitas jasa thd } \\
\text { Nilai }\end{array}$ & kualitas & 0.10 & 0.47 & 0.0470 \\
VAR1 & $\begin{array}{l}\text { jangkauan } \\
\text { jarea }\end{array}$ & & & \\
VAR3 & $\begin{array}{l}\text { kualitas } \\
\text { suara } \\
\text { kualitas } \\
\text { tingkat } \\
\text { koneksi }\end{array}$ & 0.10 & 0.47 & 0.0470 \\
VAR4 & $\begin{array}{l}\text { jaringan } \\
\text { telephon } \\
\text { kualitas } \\
\text { sinyal }\end{array}$ & 0.09 & 0.47 & 0.0470 \\
VAR2 & & 0.47 & 0.0423 \\
\hline
\end{tabular}




\begin{tabular}{|c|c|c|c|c|}
\hline VAR6 & $\begin{array}{l}\text { kualitas } \\
\text { produk } \\
\text { sesuai } \\
\text { dengan } \\
\text { slogan }\end{array}$ & 0.09 & 0.47 & 0.0423 \\
\hline VAR8 & $\begin{array}{l}\text { kualitas } \\
\text { pelayanan } \\
\text { call center } \\
\text { yang } \\
\text { responsif }\end{array}$ & 0.07 & 0.47 & 0.0329 \\
\hline VAR10 & $\begin{array}{l}\text { kualitas } \\
\text { pelayanan } \\
\text { keluhan dan } \\
\text { informasi }\end{array}$ & 0.07 & 0.47 & 0.0329 \\
\hline VAR11 & $\begin{array}{l}\text { kualitas } \\
\text { prosedur } \\
\text { pelayanan }\end{array}$ & 0.07 & 0.47 & 0.0329 \\
\hline VAR5 & $\begin{array}{l}\text { kualitas } \\
\text { teknologi } \\
\text { seluler }\end{array}$ & 0.06 & 0.47 & 0.0282 \\
\hline VAR7 & $\begin{array}{l}\text { kualitas fitur } \\
\text { dan layanan }\end{array}$ & 0.06 & 0.47 & 0.0282 \\
\hline VAR9 & $\begin{array}{l}\text { kualitas } \\
\text { pelayanan } \\
\text { call center } \\
\text { yang handal }\end{array}$ & 0.06 & 0.47 & 0.0282 \\
\hline \multicolumn{5}{|c|}{ Kualitas jasa thd Kepuasan } \\
\hline VAR1 & $\begin{array}{l}\text { kualitas } \\
\text { jangkauan } \\
\text { area }\end{array}$ & 0.10 & 0.67 & 0.0670 \\
\hline VAR3 & $\begin{array}{l}\text { kualitas } \\
\text { suara }\end{array}$ & 0.10 & 0.67 & 0.0670 \\
\hline VAR4 & $\begin{array}{l}\text { kualitas } \\
\text { tingkat } \\
\text { koneksi } \\
\text { jaringan } \\
\text { telephon }\end{array}$ & 0.10 & 0.67 & 0.0670 \\
\hline VAR2 & $\begin{array}{l}\text { kualitas } \\
\text { sinyal }\end{array}$ & 0.09 & 0.67 & 0.0603 \\
\hline VAR6 & $\begin{array}{l}\text { kualitas } \\
\text { produk } \\
\text { sesuai } \\
\text { dengan } \\
\text { slogan }\end{array}$ & 0.09 & 0.67 & 0.0603 \\
\hline VAR8 & $\begin{array}{l}\text { kualitas } \\
\text { pelayanan } \\
\text { call center } \\
\text { yang } \\
\text { responsif }\end{array}$ & 0.07 & 0.67 & 0.0469 \\
\hline VAR10 & $\begin{array}{l}\text { kualitas } \\
\text { pelayanan } \\
\text { keluhan dan } \\
\text { informasi }\end{array}$ & 0.07 & 0.67 & 0.0469 \\
\hline VAR11 & $\begin{array}{l}\text { kualitas } \\
\text { prosedur } \\
\text { pelayanan }\end{array}$ & 0.07 & 0.67 & 0.0469 \\
\hline
\end{tabular}

JURNAL

MANAJEMEN

INDONESIA

Vol.16 - No.2

APRIL 2016

Tabel 6.

Kontribusi Variabel Teramati

Terhadap Pembentukan

Konstruk

area

suara

kualitas

koneksi

jaringan

elephon

sinyal

kualitas

slogan

call center

yang

responsif

informasi

prosedur 


\section{JURNAL}

MANAJEMEN

INDONESIA

Vol.16 - No.2

\section{APRIL 2016}

Tabel 6.

Kontribusi Variabel Teramati

Terhadap Pembentukan

Konstruk

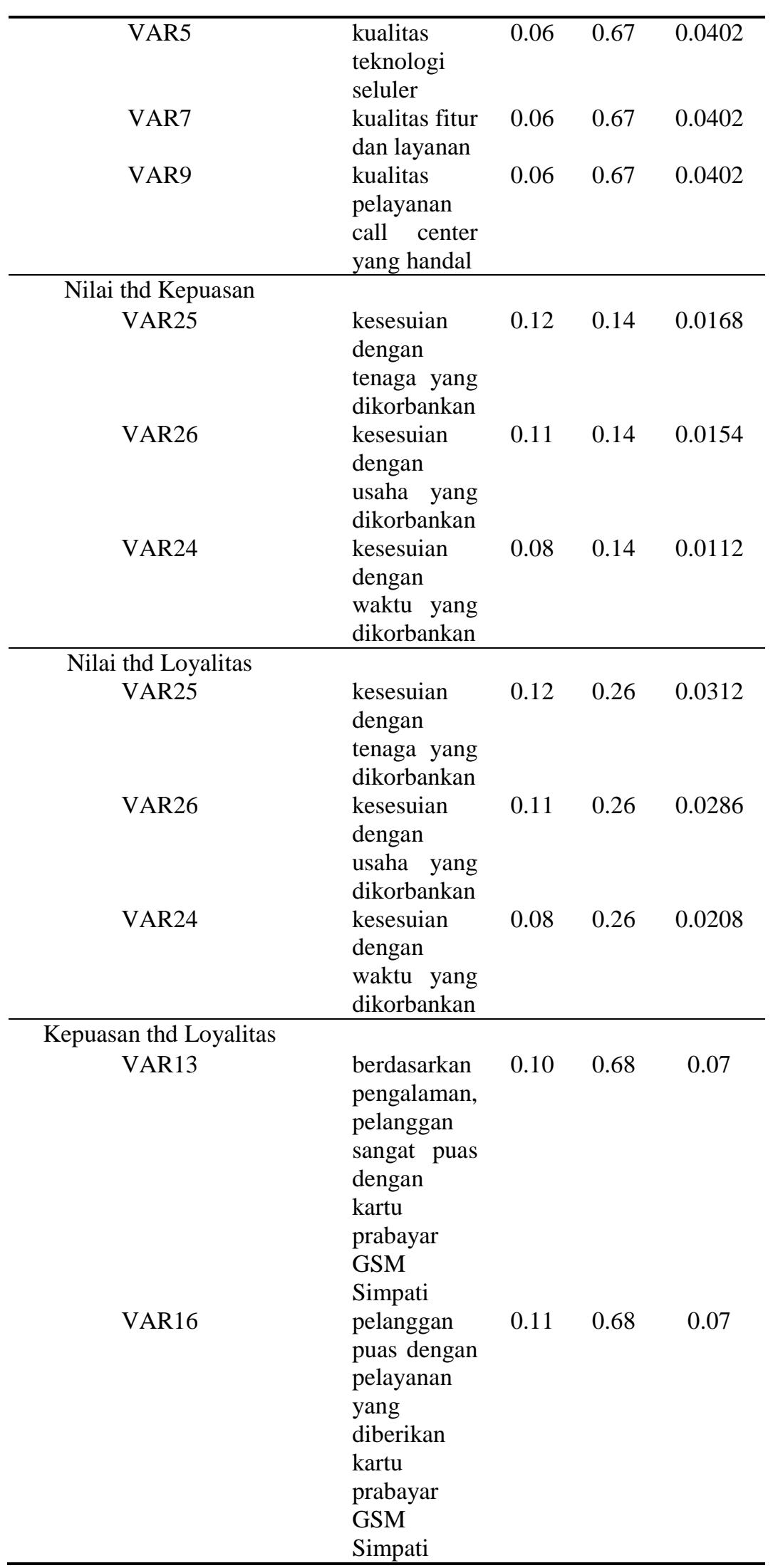




\begin{tabular}{|c|c|c|c|c|}
\hline VAR17 & $\begin{array}{l}\text { kartu } \\
\text { prabayar } \\
\text { GSM } \\
\text { Simpati } \\
\text { memberikan } \\
\text { kepuasan } \\
\text { produk }\end{array}$ & 0.09 & 0.68 & 0.06 \\
\hline VAR14 & $\begin{array}{l}\text { pelanggan } \\
\text { puas dengan } \\
\text { harga yang } \\
\text { ditawarkan } \\
\text { oleh kartu } \\
\text { prabayar } \\
\text { GSM } \\
\text { Simpati }\end{array}$ & 0.08 & 0.68 & 0.05 \\
\hline VAR15 & $\begin{array}{l}\text { pelanggan } \\
\text { puas dengan } \\
\text { kualitas } \\
\text { yang } \\
\text { ditawarkan } \\
\text { oleh kartu } \\
\text { prabayar } \\
\text { GSM } \\
\text { Simpati } \\
\end{array}$ & 0.07 & 0.68 & 0.05 \\
\hline
\end{tabular}

JURNAL

MANAJEMEN

INDONESIA

Vol.16 - No.2

APRIL 2016

Sumber: Data diolah

\subsection{Hasil dan Pembahasan}

Berdasarkan hasil analisis SEM, kualitas jasa berpengaruh positif dan signifikan terhadap kepuasan (H1) dan nilai (H2), tetapi tidak berpengaruh positif dan signifikan terhadap loyalitas pelanggan (H3). Pengaruh kualitas jasa terhadap kepuasan lebih besar daripada pengaruh kualitas jasa terhadap nilai persepsian. Hasil yang didapat pada hipotesis 1 konsisten dan sejalan dengan penelitian sebelumnya yang dilakukan Tu et al. (2011), Alireza et al. (2011), Chang \& Wang (2008), Terblanche \& Boshoff (2010). Sedangkan hipotesis 2 mendukung penelitian Tu et al. (2011), Oyeniyi \& Abiodun (2011), Alireza et al. (2011), Chang \& Wang (2008), Terblanche \& Boshoff (2010). Adapun hipotesis 3 konsisten dengan hasil yang diperoleh Tu et al. (2011), Alireza et al. (2011). Pengaruh positif dan signifikan H1 dan H2 menunjukkan bahwa peningkatan kualitas jasa akan serta merta meningkatkan nilai persepsian dan kepuasan yang dirasakan pelanggan. Walaupun peningkatan kualitas jasa tidak secara otomatis berpengaruh terhadap loyalitas pelanggan. Karena pembentukan loyalitas dipengaruhi oleh faktor-faktor lain, misalnya nilai persepsian atau kepuasan pelanggan. Oleh karena itu, kualitas jasa meliputi kualitas jangkauan area, suara, koneksi dan sinyal sesuai dengan kontribusi (tabel 6) perlu diperhatikan secara khusus oleh Telkomsel sebagai operator penyedia jasa kartu prabayar GSM Simpati.

Selanjutnya, hasil analisis SEM menunjukkan nilai persepsian berpengaruh positif dan signifikan terhadap kepuasan (H4) dan loyalitas pelanggan (H5). Temuan $\mathrm{H} 4$ mendukung dan konsisten dengan penelitian Tu et al. (2011), Oyeniyi \& Abiodun (2011), Alireza et al. (2011), Chang \& Wang (2008), Terblanche \& Boshoff (2010). Sedangkan H5 didukung dan konsisten dengan temuan Tu et al. (2011), Auka (2012), Chang \& Wang (2008). Pelanggan akan merasakan kepuasan dan menjadi loyal apabila apa yang telah mereka berikan sesuai dengan apa yang mereka terima. Timbal balik antara perusahaan penyedia jasa dan pelanggan akan membentuk nilai persepsian pelanggan. Dalam hal ini, nilai persepsian yang dimaksud meliputi kesuaian dengan pengorbanan tenaga, usaha, dan waktu pelanggan.

Pengaruh positif dan signifikan kepuasan pelanggan terhadap loyalitas (H6) konsisten dan sejalan dengan penelitian Tu et al. (2011), Oyeniyi \& Abiodun (2011), Alireza et al. (2011), Auka (2012), Chang \& Wang (2008), Terblanche \& Boshoff (2010). Peningkatan kepuasan yang dirasakan pelanggan sebagai pengaruh peningkatan kualitas jasa dan nilai persepsian akan membentuk loyalitas pelanggan. Kepuasan pelanggan terkait erat dengan pengalaman menggunakan layanan kartu prabayar GSM Simpati. Selain itu, kepuasan dirasakan pelanggan sebagai pengaruh dari harga dan kualitas yang ditawarkan Telkomsel melalui kartu prabayar GSM Simpati. 


\section{JURNAL}

MANAJEMEN

INDONESIA

Vol.16 - No.2

APRIL 2016
Penelitian ini membuktikan bahwa kualitas jasa berpengaruh signifikan terhadap persepsi nilai dan kepuasan pelanggan. Selain itu, persepsi nilai dan kepuasan pelanggan mempunyai pengaruh kuat terhadap loyalitas. Oleh karena itu, Telkomsel sebagai operator kartu prabayar GSM Simpati harus fokus terhadap faktor-faktor tersebut dengan tujuan membangun hubungan jangka panjang dan saling menguntungkan bersama pelanggan serta menciptakan loyalitas sebagai competitive advantages dalam pasar. Dengan adanya loyalitas diharapkan pelanggan bertahan menggunakan kartu prabayar GSM Simpati walaupun kartu prabayar lain menawarkan tarif yang lebih murah. Selain itu, pelanggan dapat merekomendasikan dan memberikan word of mouth positif tentang kualitas jasa yang ditawarkan kartu prabayar GSM Simpati.

\section{Kesimpulan}

Pengujian hipotesis menunjukkan bahwa 5 dari 6 hipotesis dapat diterima. Dari hasil pengujian, disimpulkan bahwa untuk membentuk loyalitas pelanggan kartu prabayar GSM Simpati dapat dilakukan melalui peningkatan kualitas jasa yang ditawarkan. Walaupun pengaruh kualitas jasa terhadap loyalitas tidak secara langsung, tetapi kualitas jasa berpengaruh langsung terhadap nilai persepsian dan kepuasan pelanggan. Kedua faktor ini pada akhirnya akan berpengaruh secara positif dan signifikan terhadap loyalitas pelanggan kartu prabayar GSM Simpati.

\section{Daftar Pustaka}

Alireza, F., Ali, K. dan Aram, F. 2011. How quality, value, image, and satisfaction create loyalty at an Iran Telecom. International Journal of Business and Management, Vol. 6, No. 8.

Auka, D.O. 2012. Service quality, satisfaction, perceived value and loyalty among customers in commercial banking in Nakuru Municipality, Kenya. African Journal of Marketing Management, Vol. 4(5), pp. 185 - 203.

Bentler, P.M dan Chou, C. 1987. Practical Issues In Structural Modelling. Sosiological Methods and Research. 16, 78-117.

Boshoff, C. dan Gray, B. 2004. The relationships between service quality, customer satisfaction and buying intentions in the private hospital industry, South African Journal of Business Management, Vol. 35 No. 4, pp. 27 - 37.

Bowen, J.T. dan Shoemaker, S. 2003. Loyalty: A strategic commitment. Cornell Hotel \& Restaurant Administration Quarterly, 44(5/6), 31 - 46.

Butz, J.H.E. dan Goodstein, L. 1996. Measuring customer value: gaining the strategic advantage. Organizational Dynamic, 24(3), 63 - 77.

Chang, H.H. dan Wang, H.W. 2008. The relationships among e-service quality, value, satisfaction and loyalty in online shopping. European Advances in Consumer Research, Vol. 8.

Dick, A.S. dan Basu, K. 1994. Customer loyalty: Toward an integrated conceptual framework. Journal of Academy of Marketing Science, 22(2), 99 - 113.

Eakuru, N. dan Mat, N.K.N. 2008. The application of structural equation modeling (SEM) in determining the antecedents of customer loyalty in banks in South Thailand. The Business Review Cambridge, 10(2), 129 - 139.

Gilbert, G.R. dan Veloutsou, C. 2006. A cross-industry comparison of customer customer satisfaction. The Journal of Service Marketing, Vol. 20 No. 5, pp. 298 - 308.

Hair, J.F. Jr. , Anderson, R.E., Tatham, R.L., \& Black, W.C. 1998. Multivariate Data Analysis, ( $5^{\text {th }}$ Edition). Upper Saddle River, NJ: Prentice Hall.

Ibrahim, H. dan Najjar, F. 2008. Relationship bonding tactics, personality traits, relationship quality and customer loyalty: Behavioral sequence in retail environment. The Icfai University Journal of Services Marketing, Vol. 6 No. 4, pp. 1 - 37.

Jain, S.K. dan Gupta, G. 2004. Measuring service quality: SERVQUAL vs SERVPERF scales, VIKALPA, Vol. 29 No. 2, pp. $25-37$.

Khan, M.A. 2010. An empirical assessment of service quality of cellular mobile telephone operators in Pakistan, Asian Social Science, Vol. 6 No. 10, pp. $164-177$.

Kotler, P. 2005. According to Kotler: The World's Foremost Authority on Marketing Answers the World's Foremost Authority on Marketing Answers Your Questions, New York: AMACOM. 
Lee, E.J. dan Overby, J.W. 2004. Creating value for online shoppers: Implications for satisfaction and loyalty. Journal of Consumer Satisfaction, Dissatisfaction and Complaining Behavior, 17, 54 - 57.

Moliner, M.A., Sanchez, J., Rodriguez, R.M. dan Callarisa, L. 2007. Relationship quality with a travel agency: The influence of the post - purchase perceived value of a tourism package, Tourism and Hospitality Research, Vol. 7 No. 3, pp. $194-211$.

Oliver, R.L. 1997. Satisfaction: A Behavioral Perspective on the Consumer. New York: McGraw - Hill.

Oyeniyi, O. dan Abiodun, A.J. 2011. Service quality, value offer, satisfaction and loyalty: an Empirical relationship in the Nigerian telecom industry. The Journal Contemporary Management Research, Vol. 5, No. 2, $14-23$.

Prahadi, Y.Y. 2015. Jutaan Kartu SIM Hangus Tiap Bulan, Perketat Registrasi [Online]. Tersedia pada : http://swa.co.id/business-strategy/jutaan-kartu-sim-hangus-tiap-bulanperketat-registrasi. [Diakses 19 Juni 2015]

Reichheld, F.F. dan Detrick, C. 2003. Loyalty: A prescription for cutting costs. Marketing Management, 12(5), $24-25$. dan Teal, T. 1996. The Loyalty Effect. Boston: Harvard Business School.

dan Sasser, W.E. 1990. Zero defections: Quality comes to services. Harvard Business Review, 68(5), 105 - 111.

Roig, J.G.F., Garcia, J.S., Tena, M.A.M. dan Monzonis, J.L. 2006. Customer perceived value in banking services, International Journal of Bank Marketing, Vol. 24 No. 5, pp. 266 - 283.

Rust, R.T., Lemon, K.N. dan Zeithaml, V.A. 2004. Return on marketing: Using customer equity to focus marketing strategy. Journal of Marketing, 68(1), 109 - 127.

Spreng, R.A. dan Mackoy, R.D. 1996. An empirical examination of a model of perceived service quality and satisfaction. Journal of Retailing, 72 (2), 201 - 14.

Taylor, S.A. dan Baker, T.L. 1994. An assessment of the relationship between service quality and customer satisfaction in the formation of consumers' purchase intentions, Journal of Retailing, Vol. 70 No. 2, pp. $163-78$.

Terblanche, N.S. dan Boshoff, C. 2010. Quality, value, satisfaction and loyalty amongst race groups: A study of customers in the South African fast food industry. South African Journal of Business Management, 41(1).

Tu, Y.T., Li, M.L. dan Chih, H.C. 2011. The effect of service quality, customer perceived value and satisfaction on loyalty. Journal of Economics and Behavioral Studies, Vol. 3, No. 3, pp. $198-212$.

Wijanto, S.H. 2008. Structural Equation Modeling dengan Lisrel 8.8 Konsep dan Tutorial, Graha Ilmu.

Wils, B. 2009. The business case for environmental sustainability (Green): Achieving rapid returns from the practical integration of lean \& green. Business Case for Environmental Sustainability [Online]. Tersedia pada: http://www.leanandgreensummit.com/LGBC.pdf [Diakses April 2013]

Woodruff, R.B. 1997. Customer value: The next source for competitive advantage. Academy of Marketing Science, 25(2), 139 - 153.

Zeithaml, V.A. 1988. Consumers' perceptions of price, quality, and value: a means-end model and synthesis of evidence. Journal of Marketing, Vol. 52, July, pp. 2 - 22. 